GROUP SELEGTION IN

Predator-Prey

Communities 


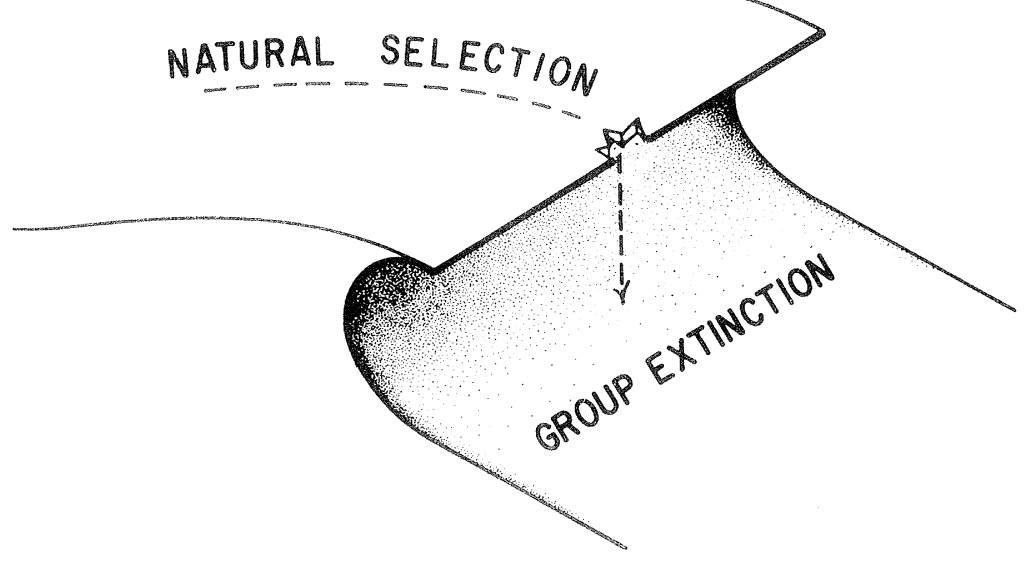




\title{
GROUP SELECTION IN
}

\section{Predator-Prey Communities}

\author{
MICHAEL E. GILPIN
}

\author{
PRINGETON, NEW JERSEY
}

PRINGETON UNIVERSITY PRESS

1975 


\section{MONOGRAPYS IN POPULATION BIOLOGY}

\section{EDYTED BY ROBERT M. MAX}

1. The Theory of Island Biogeography, by Robert H. MacArthur and Edward O. Wilson

2. Evolution in Changing Environments: Some Theoretical Explorations, by Richard Levins

3. Adaptive Geometry of 'Trees, by Henry S. Horn

4. Theoretical Aspects of Population Genetics, by Motoo Kimura and Tomoko Ohta

5. Populations in a Seasonal Environment, by Stephen D. Fretwell

6. Stability and Complexity in Model Ecosystems, by Robert M. May

7. Competition and the Structure of Bird Communities, by Martin Cody

8. Sex and Evolution, by George C. Williams

9. Group Selection in Predator-Prey Communities, by Michael E. Gilpin

Copyright (C) 1975 by Princeton University Press

Published by Princeton University Press, Princeton and London

ALL RIGHTS RESERVED

Library of Congress Cataloging in Publication data

will be found on the last printed page of this book

This book has been composed in Monotype Baskerville

Printed in the United States of America

by Princeton University Press, Princeton, New Jersey 
This book is dedicated to

R O B E R H . M A A R THUR, who blazed trails into many unexplored regions of population biology, including the one traveled here. 
